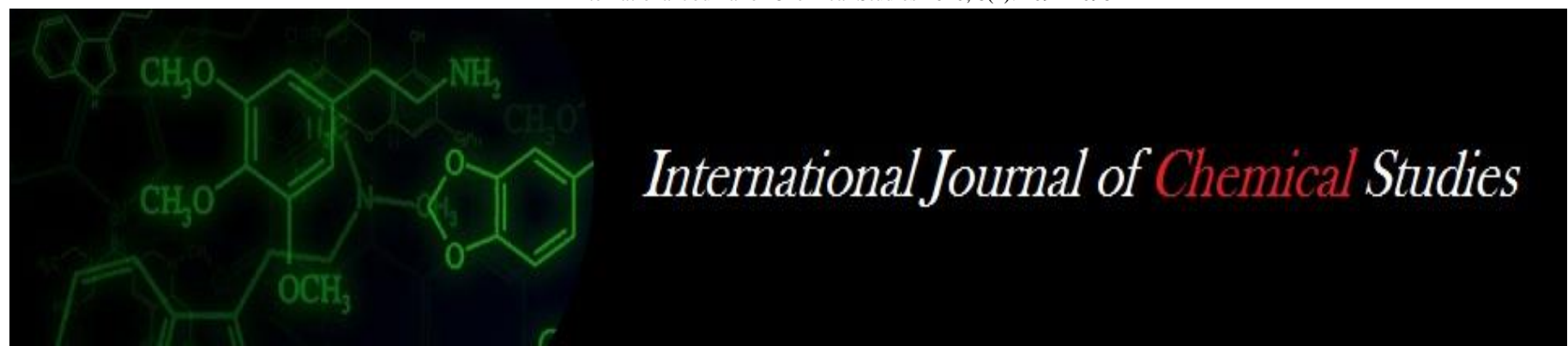

P-ISSN: 2349-8528

E-ISSN: 2321-4902

IJCS 2020; 8(1): 2094-2098

(C) 2020 IJCS

Received: 22-11-2019

Accepted: 24-12-2019

\section{Alpana Kusum}

Presently Ph.D. Scholar,

Department of Soil Science and

Agricultural Chemistry, Bihar

Agricultural University, Sabour,

Bihar, India

Shankar Jha

Department of Soil Science,

Dr. Rajendra Prasad Central

Agricultural University, Pusa,

Bihar, India

SS Prasad

Department of Soil Science,

Dr. Rajendra Prasad Central

Agricultural University, Pusa,

Bihar, India

\section{SP Singh}

Department of Soil Science,

Dr. Rajendra Prasad Central

Agricultural University, Pusa,

Bihar, India

\section{Corresponding Author:}

Alpana Kusum

Presently Ph.D. Scholar,

Department of Soil Science and

Agricultural chemistry, Bihar

Agricultural University, Sabour,

Bihar, India

\section{Effect of household waste based vermicompost and fertilizer on phosphorus and potassium mineralization in calcareous soil of Bihar}

\author{
Alpana Kusum, Shankar Jha, SS Prasad and SP Singh
}

DOI: https://doi.org/10.22271/chemi.2020.v8.i1ae.8575

\begin{abstract}
An incubation experiment was conducted during Kharif 2018 at RPCAU, Pusa to examine the mineralization of vermicompost in calcareous sandy loam soil at five different stages which match with the critical growth stages of rice crop and the experiment was conducted in Completely Randomized design (3 factors) replicated thrice. There were four levels of vermicompost along with three levels of chemical fertilizers used at field capacity $(19.47 \%)$ in combinations and alone. Results indicated that content of available $\mathrm{P}_{2} \mathrm{O}_{5}$ and $\mathrm{K}_{2} \mathrm{O}$ in soil increased up to 65 DAI then decreased gradually. Application of increasing level of vermicompost and fertilizer alone or in combination resulted in corresponding increase in the available nutrient content of soil. During the study, it was observed that the treatment combination involving application of highest dose of vermicompost $\left(3.75 \mathrm{t} \mathrm{ha}^{-1}\right)$ along with full dose of fertilizer (RDF) was significantly superior.
\end{abstract}

Keywords: Household waste, vermicompost, incubation study, phosphorus, potassium

\section{Introduction}

In order to meet the requirement of ever-increasing population and promote food security it is important to increase the production of crop to a higher level. Ever since green revolution in 1960 's, use of high yielding varieties, chemical fertilizers and pesticides and others have tremendously increased food grain production in India as well as world. But subsequent use of chemical fertilizers and injudicious fertilizer management along with adoption of inadequate agricultural practices over years have led to deterioration in soil health and soil fertility. The increasing cost of fertilizers and its undesirable effects on soil properties have led to inclusion of organic manures as a supplement to chemical fertilizers in crop cultivation. Organic matter plays a prominent role in improving soil fertility and sustaining the soil productivity. Organic wastes are rich in nutrients which can be converted to plant available form by vermicomposting. Analysis conducted by National Environmental Engineering Research Institute (2005) reveals that on an average domestic waste in India consists Nitrogen $(0.64 \pm$ $0.8) \%$, Phosphorus $(0.67 \pm 0.15) \%$, Potassium $(0.68 \pm 0.15) \%$ with $\mathrm{C}: \mathrm{N}$ ratio $(26 \pm 5) \%$. Vermicompost usually contains higher levels of most of the mineral elements such as nitrates, exchangeable phosphorus, and soluble potassium, calcium, and magnesium which are in available forms than the substrate (Edwards and Bohlen, 1996) [2]. As a result of vermicomposting the concentration of nutrients increases remarkably in organic wastes (Haiba et al., 2014) ${ }^{[3]}$. It is widely reported in several literatures that neither use of organic manures alone nor chemical fertilizers can achieve the sustainability of the yield and use of chemical fertilizers alone will overtime deteriorate soil health. The importance of vermicompost as a source of humus and in improving the soil fertility and soil health has been well established (Madegowda, 1997; Vasanthi and Kumaraswamy, 1996; Romaniuk et al.,2011 and Murugan and Swarnam 2013) ${ }^{[12,11,10]}$.

Keeping these in view, the present studies were carried out to understand the phosphorus and potassium mineralization pattern in soil on application of household waste based vermicompost alone or in combination with fertilizer. 


\section{Materials and Methods}

An incubation experiment was conducted in sandy loam soil of Dr. Rajendra Prasad Central Agricultural University, Pusa, Samastipur, Bihar during Kharif 2018. The soil of experimental site belongs to order Entisol and is characterized as Calciorthents which is sandy loam in texture with alkaline $\mathrm{pH}$ (8.06), low in available $\mathrm{N}\left(220 \mathrm{~kg} \mathrm{ha}^{-1}\right)$ and $\mathrm{P}(17.80 \mathrm{~kg}$ $\mathrm{ha}^{-1}$ ) while medium in available $\mathrm{K}\left(146.5 \mathrm{~kg} \mathrm{ha}^{-1}\right)$.

For study four levels of household waste based vermicompost and three levels of fertilizers were used at field capacity $(19.47 \%)$ in combinations and alone.

Experimental design - Completely Randomized Design (Factorial)

Replication - 3

Factor - 3

\section{Factor I - Stages of study (S)}

$\begin{array}{lll}\mathrm{S}_{1} & : & 0 \text { day } \\ \mathrm{S}_{2} & : & \text { 30 days after incubation (DAI) } \\ \mathrm{S}_{3} & : & \text { 65 DAI } \\ \mathrm{S}_{4} & : & 100 \mathrm{DAI} \\ \mathrm{S}_{5} & : & 120 \mathrm{DAI}\end{array}$

\section{Factor II - Four levels of vermicompost (V)}

$\mathrm{V}_{0} \quad$ : $\quad$ No. manure

$\mathrm{V}_{1} \quad$ : $\quad$ Vermicompost @ $1.25 \mathrm{tha}^{-1}$

$\mathrm{V}_{2} \quad: \quad$ Vermicompost @ $2.5 \mathrm{tha}^{-1}$

$\mathrm{V}_{3} \quad$ : $\quad$ Vermicompost@ $3.75 \mathrm{tha}^{-1}$
Factor III - Three levels of fertilizers (F)

$\mathrm{F}_{0} \quad$ : $\quad$ No. fertilizer

$\mathrm{F}_{1} \quad$ : $\quad \mathrm{RDF}$

$\mathrm{F}_{2} \quad: \quad 50 \% \mathrm{RDF}$

RDF- (N: $\mathrm{P}_{2} \mathrm{O} 5: \mathrm{K}_{2} \mathrm{O}: 120: 60: 40 \mathrm{~kg} \mathrm{ha}^{-1}$ )

- No. of pots and capacity - 180 boxes and $200 \mathrm{~g}$ capacity for each box

The vermicompost and $\mathrm{N}, \mathrm{P}$ and $\mathrm{K}$ fertilizers were thoroughly mixed as per requirement with $200 \mathrm{~g}$ soil in each box according to the treatments and the soil was brought to field capacity. The field capacity of the soil was maintained throughout the incubation period. Soil samples were analyzed for available $\mathrm{P}$ and $\mathrm{K}$ at 5 different stages of incubation i.e. at 0 day, 30 days after incubation (DAI), 65 DAI, 100 DAI and 120 DAI which match with the critical stages of rice crop.

The available phosphorus for soil sample was measured by the procedure given by Olsen et al. (1954) ${ }^{[7]}$, at $660 \mathrm{~nm}$ wavelength. Whereas, available potassium was determined by flame photometer after extracting the soil with neutral normal ammonium acetate as described by Jackson (1978).

\section{Results and discussion \\ Available Phosphorus (kg ha-1)}

The Table 1a shows the impact of graded doses of vermicompost either alone or in combination with different fertilizers levels on status of available phosphorus content $(\mathrm{kg}$ $\mathrm{ha}^{-1}$ ) in soil during the incubation period.

Table 1a: Effect of vermicompost and fertilizer on $\mathrm{P}$ mineralization

\begin{tabular}{|c|c|c|c|c|c|c|}
\hline \multicolumn{7}{|c|}{$\begin{array}{ll}\text { Available } \mathrm{P}_{2} \mathrm{O}_{5}\left(\mathrm{~kg} \mathrm{ha}^{-1}\right) \\
\end{array}$} \\
\hline \multicolumn{6}{|c|}{$S_{1}(0$ day after incubation) } & \\
\hline & $\mathbf{V}_{\mathbf{0}}$ & $V_{1}$ & $\mathbf{V}_{2}$ & $\mathbf{V}_{\mathbf{3}}$ & Mean & \\
\hline $\mathrm{F}_{0}$ & 18.37 & 20.36 & 21.25 & 22.36 & 20.59 & \\
\hline $\mathrm{F}_{1}$ & 23.68 & 25.03 & 26.29 & 26.37 & 25.34 & \\
\hline $\mathrm{F}_{2}$ & 22.60 & 23.64 & 22.67 & 23.67 & 23.15 & \\
\hline Mean & 21.55 & 23.01 & 23.40 & 24.13 & & \\
\hline \multicolumn{6}{|c|}{$S_{2}$ (30 days after incubation) } & \\
\hline & $\mathbf{V}_{0}$ & $V_{1}$ & $\mathbf{V}_{2}$ & $\mathbf{V}_{3}$ & Mean & \\
\hline $\mathrm{F}_{0}$ & 22.09 & 23.12 & 23.19 & 25.22 & 23.41 & \\
\hline $\mathrm{F}_{1}$ & 29.46 & 32.18 & 34.32 & 34.73 & 32.67 & \\
\hline $\mathrm{F}_{2}$ & 24.60 & 27.05 & 27.32 & 32.19 & 27.79 & \\
\hline Mean & 25.38 & 27.45 & 28.28 & 30.71 & & \\
\hline \multicolumn{6}{|c|}{$S_{3}$ (65 days after incubation) } & \\
\hline & $\mathbf{V}_{0}$ & $\mathbf{V}_{1}$ & $\mathbf{V}_{2}$ & $\mathbf{V}_{3}$ & Mean & \\
\hline $\mathrm{F}_{0}$ & 25.86 & 26.75 & 27.27 & 27.91 & 26.95 & \\
\hline$F_{1}$ & 29.11 & 31.49 & 32.67 & 33.76 & 31.76 & \\
\hline $\mathrm{F}_{2}$ & 28.06 & 28.57 & 29.19 & 30.76 & 29.14 & \\
\hline Mean & 27.68 & 28.94 & 29.71 & 30.81 & & \\
\hline \multicolumn{6}{|c|}{$\mathrm{S}_{\mathbf{4}}$ (100 days after incubation) } & \\
\hline & $\mathbf{V}_{0}$ & $\mathrm{~V}_{1}$ & $\mathbf{V}_{2}$ & $\mathbf{V}_{3}$ & Mean & \\
\hline $\mathrm{F}_{0}$ & 23.53 & 23.60 & 24.90 & 24.93 & 24.24 & \\
\hline $\mathrm{F}_{1}$ & 26.09 & 30.79 & 31.47 & 32.17 & 30.13 & \\
\hline $\mathrm{F}_{2}$ & 25.53 & 27.37 & 28.67 & 29.90 & 27.87 & \\
\hline Mean & 25.05 & 27.25 & 28.34 & 29.00 & & \\
\hline \multicolumn{6}{|c|}{$\mathrm{S}_{5}$ (120 days after incubation) } & \multirow{2}{*}{ Grand mean (Fertilizer) } \\
\hline & $\mathbf{V}_{0}$ & $V_{1}$ & $\mathbf{V}_{2}$ & $\mathbf{V}_{3}$ & Mean & \\
\hline $\mathrm{F}_{0}$ & 19.73 & 20.83 & 21.45 & 22.40 & 21.10 & 23.05 \\
\hline $\mathrm{F}_{1}$ & 23.77 & 25.83 & 28.00 & 29.31 & 26.73 & 29.33 \\
\hline $\mathrm{F}_{2}$ & 20.53 & 22.90 & 24.53 & 26.19 & 23.54 & 26.30 \\
\hline Mean & 21.34 & 23.19 & 24.66 & 25.97 & & \\
\hline Grand mean (Vermicompost) & 24.20 & 25.97 & 26.88 & 28.13 & & \\
\hline
\end{tabular}

\begin{tabular}{|c|c|c|}
\hline Factors & SEm( \pm ) & CD (5\%) \\
\hline Factor $(S)$ & 0.119 & 0.334 \\
\hline Factor $(V)$ & 0.107 & 0.299 \\
\hline
\end{tabular}




\begin{tabular}{|c|c|c|}
\hline Interaction S x V & 0.239 & 0.668 \\
\hline Factor (F) & 0.092 & 0.259 \\
\hline Interaction S x F & 0.207 & 0.579 \\
\hline Interaction V x F & 0.185 & 0.518 \\
\hline Interaction S x V x F & 0.414 & 1.159 \\
\hline
\end{tabular}

The result indicated that irrespective of incubation stages, higher value of vermicompost level recorded significantly higher content of $\mathrm{P}_{2} \mathrm{O}_{5}$ and it ranged from 24.20 to $28.13 \mathrm{~kg}$ ha $^{-1}$ whereas highest level of fertilizer dose gave significantly higher value of available $\mathrm{P}_{2} \mathrm{O}_{5}$ and it varied from 23.05 to $29.33 \mathrm{~kg} \mathrm{ha}^{-1}$.

Irrespective of fertilizer level, there was corresponding increase in $\mathrm{P}_{2} \mathrm{O}_{5}$ up to $65 \mathrm{DAI}$ for vermicompost levels (0 to $2.5 \mathrm{t} \mathrm{ha}^{-1}$ ) and declined thereafter. The content of $\mathrm{P}_{2} \mathrm{O}_{5}$ during starting of incubation ranged from 21.55 to $24.13 \mathrm{~kg} \mathrm{ha}^{-1}$, 25.38 to $30.71 \mathrm{~kg} \mathrm{ha}^{-1}$ at $30 \mathrm{DAI}, 27.68$ to $30.81 \mathrm{~kg} \mathrm{ha}^{-1}$ at 65 DAI, 25.05 to $29.00 \mathrm{~kg} \mathrm{ha}^{-1}$ at $100 \mathrm{DAI}$ and 21.34 to $25.97 \mathrm{~kg}$ $\mathrm{ha}^{-1}$ at $120 \mathrm{DAI}$.

The treatment receiving highest dose of vermicompost $(3.75 \mathrm{t}$ $\mathrm{ha}^{-1}$ ) along with RDF was found to be significantly superior to rest of the treatments. However, the treatments receiving only vermicompost as the nutrient source recorded significant increase in $\mathrm{P}_{2} \mathrm{O}_{5}$ content up to 65 DAI $\left(26.98 \mathrm{~kg} \mathrm{ha}^{-1}\right)$ and it confirms the findings of Jatgar (1994) ${ }^{[5]}$. The increase in available phosphorus might be due to the fact that application of vermicompost increases organic matter content and microbial activity. Hence, production of organic acids during decomposition of organic matter by microbes which might have solubilized the unavailable forms of phosphorus.

Irrespective of vermicompost doses, treatment combinations receiving highest dose of fertilizer recorded significantly higher content of available $\mathrm{P}_{2} \mathrm{O}_{5}$ at 30 DAI $\left(32.67 \mathrm{~kg} \mathrm{ha}^{-1}\right)$. However, application of $50 \%$ RDF resulted in increase in content of available phosphorus up to 65 DAI which declined thereafter. Dubey et al. (2012) ${ }^{[1]}$ reported that balanced use of fertilizer alone resulted in significant increase in available phosphorus in soil.

The data shows that significantly higher content of available $\mathrm{P}_{2} \mathrm{O}_{5}$ in soil was recorded with application of highest dose of vermicompost $\left(3.75 \mathrm{t} \mathrm{ha}^{-1}\right)$ in combination with full dose of fertilizer and it was found to be at par with the treatment receiving vermicompost @ $2.5 \mathrm{tha}^{-1}$ and full dose of chemical fertilizer up to 65 DAI. The increase in available phosphorus content of the soil up to 65 days of incubation period may be due to the build-up of $\mathrm{P}_{2} \mathrm{O}_{5}$ owing to application of vermicompost or any organic material.

At 120 DAI, $\mathrm{P}_{2} \mathrm{O}_{5}$ content in soil ranged from 19.73 to 29.31 $\mathrm{kg} \mathrm{ha}^{-1}$ and treatment with highest dose of vermicompost (3.75 $\mathrm{t} \mathrm{ha}^{-1}$ ) in combination with $100 \%$ RDF was significantly superior $\left(29.31 \mathrm{~kg} \mathrm{ha}^{-1}\right)$. The data reveals that interaction of vermicompost and chemical fertilizer significantly influenced the available phosphorus content of soil during the incubation period and increasing level of vermicompost and chemical fertilizer resulted in corresponding increase in the available $\mathrm{P}$ content of soil. The percent increase observed was higher with combination of vermicompost and chemical fertilizer as compared to their alone application. The results were in tunes with the findings of Manivannan et al. (2009) ${ }^{[9]}$.

The increase in available phosphorus due to organic materials application would also be attributed to the fact that phosphorus can be adsorbed by organic matter, the clay complex and the chelating compounds. Organic acids released during the decomposition of organic matter affect phosphate solubilisation and fixation. Phosphorus solubilizes such as
Aspergillus awamorii, Bacillus polymyxa, Bacillus megatherium might be responsible for solubilizing phosphates as well. Organic manures application in soil influences $\mathrm{P}$ fixation both directly and indirectly (Jatgar 1994) ${ }^{[5]}$.

The treatment receiving highest dose of vermicompost $(3.75 \mathrm{t}$ $\mathrm{ha}^{-1}$ ) in combination with full dose of fertilizer recorded $59.55 \%, 89.05 \%, 83.78 \%, 75.12 \%$ and $59.55 \%$ increase over control at $0,30,65,100$ and 120 days after incubation. The interaction effects were found significant.

\section{Available potassium ( $\left.\mathrm{kg} \mathrm{ha}^{-1}\right)$}

The results obtained for available potassium content in soil during the incubation study have been presented in Table $1 \mathrm{~b}$. A scrutiny of data indicated that irrespective of incubation stages, increasing value of vermicompost level recorded significant increase in the content of $\mathrm{K}_{2} \mathrm{O}$ and it varied from 205.62 to $236.02 \mathrm{~kg} \mathrm{ha}^{-1}$ whereas highest level of fertilizer dose gave significantly higher value of available potassium which varied from 193.63 to $245.45 \mathrm{~kg} \mathrm{ha}^{-1}$.

Irrespective of fertilizer level, there was significant increase in $\mathrm{K}_{2} \mathrm{O}$ up to 65 DAI which declined thereafter and is in accordance with findings of Jatgar (1994) ${ }^{[5]}$. The content of $\mathrm{K}_{2} \mathrm{O}$ during starting of incubation ranged from 203.33 to $226.34 \mathrm{~kg} \mathrm{ha}^{-1}, 217.64$ to $235.86 \mathrm{~kg} \mathrm{ha}^{-1}$ at $30 \mathrm{DAI}, 218.40$ to $244.89 \mathrm{~kg} \mathrm{ha}^{-1}$ at $65 \mathrm{DAI}, 197.81$ to $239.90 \mathrm{~kg} \mathrm{ha}^{-1}$ at $100 \mathrm{DAI}$ and 190.91 to $233.13 \mathrm{~kg} \mathrm{ha}^{-1}$ at $120 \mathrm{DAI}$. The treatment receiving highest dose of vermicompost (3.75 $\left.\mathrm{t} \mathrm{ha}^{-1}\right)$ along with RDF was observed significantly superior to rest of the treatments. Increase in available potassium in soil up to 65 days of incubation might be due to mineralization and immobilization of nutrients as a result of organic matter decomposition

The data also indicated that irrespective of vermicompost doses, content of available potassium as influenced by different doses of fertilizer was observed significantly higher at 65 DAI which varied from 204.06 to $255.66 \mathrm{~kg} \mathrm{ha}^{-1}$. The treatment receiving higher dose of fertilizer recorded significantly higher content of available K. Dubey et al. (2012) ${ }^{[1]}$ reported that balanced use of fertilizer alone resulted in significant increase in available $\mathrm{K}$ in soil.

At 120 DAI, soil available potassium content varied from 169.05 to $236.60 \mathrm{~kg} \mathrm{ha}^{-1}$ and treatment with highest dose of vermicompost $\left(3.75 \mathrm{t} \mathrm{ha}^{-1}\right)$ in combination with full dose of fertilizer was significantly superior $\left(236.60 \mathrm{~kg} \mathrm{ha}^{-1}\right)$. The results indicated that interaction of vermicompost and chemical fertilizer significantly influenced the available potassium content of soil during the incubation period and increasing level of vermicompost and chemical fertilizer resulted in corresponding increase in the available potassium content of soil. The percent increase observed was higher with combination of vermicompost and chemical fertilizer as compared to their alone application. The beneficial effect of vermicompost on the available $\mathrm{K}$ was also due to reduction in fixation and release of $\mathrm{K}$ due to interaction of organic matter with clay as well as direct addition of $\mathrm{K}$ in the available $\mathrm{K}$ pool of soil (Washimkar, 1997) ${ }^{[13]}$. Increase in available potassium due to application of vermicompost during the incubation study was also reported by Jatgar (1994) ${ }^{[5]}$ and Washimkar (1997) ${ }^{[13]}$. 
The treatment receiving highest dose of vermicompost $(3.75 \mathrm{t}$ $\mathrm{ha}^{-1}$ ) in combination with full dose of fertilizer recorded $38.72 \%, 43.27 \%, 49.62 \%, 34.09 \%$ and $31.12 \%$ increase over control at $0,30,65,100$ and 120 days after incubation.

The overall trend showed that available $\mathrm{K}_{2} \mathrm{O}$ content increased significantly with increasing levels of vermicompost up to $3.75 \mathrm{t} \mathrm{ha}^{-1}$ and $100 \% \mathrm{RDF}$. Similar trend of data followed at all the time period i.e., 0, 30, 65, 100 and 120 DAI.

Available potassium content in soil on application of vermicompost @ $2.5 \mathrm{t} \mathrm{ha}^{-1}\left(228.07 \mathrm{~kg} \mathrm{ha}^{-1}\right)$ was found to be at par with the treatments receiving 50\% RDF $\left(228.84 \mathrm{~kg} \mathrm{ha}^{-1}\right)$. Thus, with application of vermicompost @ $2.5 \mathrm{t} \mathrm{ha}^{-1}$ saving of 1.25 tonnes of vermicompost as well as $50 \%$ of fertilizer can be done. interaction effects were found significant.

Table 1b: Effect of vermicompost and fertilizer on K mineralization

\begin{tabular}{|c|c|c|c|c|c|c|}
\hline \multicolumn{7}{|c|}{ Available $\mathrm{K}_{2} \mathrm{O}\left(\mathrm{kg} \mathrm{ha}^{-1}\right)$} \\
\hline \multicolumn{6}{|c|}{$S_{1}(0$ day after incubation) } & \\
\hline & $\mathbf{V}_{\mathbf{0}}$ & $\mathbf{V}_{1}$ & $\mathbf{V}_{2}$ & $\mathbf{V}_{3}$ & Mean & \\
\hline $\mathrm{F}_{0}$ & 180.45 & 181.93 & 187.60 & 188.63 & 184.65 & \\
\hline $\mathrm{F}_{1}$ & 229.27 & 241.36 & 248.70 & 250.33 & 242.41 & \\
\hline $\mathrm{F}_{2}$ & 200.27 & 214.53 & 221.10 & 240.07 & 218.99 & \\
\hline Mean & 203.33 & 212.61 & 219.13 & 226.34 & & \\
\hline \multicolumn{6}{|c|}{$S_{2}$ (30 days after incubation) } & \\
\hline & $\mathbf{V}_{\mathbf{0}}$ & $\mathbf{V}_{1}$ & $\mathbf{V}_{2}$ & $\mathbf{V}_{3}$ & Mean & \\
\hline $\mathrm{F}_{0}$ & 196.52 & 198.23 & 198.23 & 203.00 & 199.00 & \\
\hline $\mathrm{F}_{1}$ & 235.07 & 249.03 & 252.50 & 258.53 & 248.78 & \\
\hline $\mathrm{F}_{2}$ & 221.33 & 235.33 & 238.23 & 246.03 & 235.23 & \\
\hline Mean & 217.64 & 227.53 & 229.65 & 235.86 & & \\
\hline \multicolumn{6}{|c|}{$\mathrm{S}_{3}$ (65 days after incubation) } & \\
\hline & $\mathbf{V}_{0}$ & $\mathbf{V}_{1}$ & $\mathbf{V}_{2}$ & $\mathbf{V}_{3}$ & Mean & \\
\hline $\mathrm{F}_{1}$ & 238.63 & 256.23 & 257.47 & 270.30 & 255.66 & \\
\hline $\mathrm{F}_{2}$ & 224.13 & 235.33 & 244.13 & 253.10 & 239.17 & \\
\hline Mean & 218.40 & 229.36 & 237.21 & 244.89 & & \\
\hline \multicolumn{6}{|c|}{$\mathrm{S}_{4}(100$ days after incubation) } & \\
\hline & $\mathbf{V}_{0}$ & $\mathrm{~V}_{1}$ & $\mathbf{V}_{2}$ & $\mathbf{V}_{3}$ & Mean & \\
\hline $\mathrm{F}_{0}$ & 175.47 & 180.53 & 194.98 & 198.13 & 194.45 & \\
\hline $\mathrm{F}_{1}$ & 207.33 & 230.37 & 240.44 & 241.97 & 241.94 & \\
\hline $\mathrm{F}_{2}$ & 210.63 & 211.20 & 217.80 & 234.83 & 228.67 & \\
\hline Mean & 197.81 & 218.74 & 230.29 & 239.90 & & \\
\hline \multicolumn{6}{|c|}{$\mathrm{S}_{5}$ (120 days after incubation) } & \multirow{2}{*}{ Grand mean (Fertilizer) } \\
\hline & $\mathbf{V}_{0}$ & $V_{1}$ & $V_{2}$ & $\mathbf{V}_{3}$ & Mean & \\
\hline $\mathrm{F}_{0}$ & 169.05 & 174.40 & 187.06 & 193.33 & 185.99 & 193.63 \\
\hline$F_{1}$ & 203.14 & 221.40 & 226.40 & 236.60 & 238.43 & 245.45 \\
\hline $\mathrm{F}_{2}$ & 200.53 & 204.57 & 211.50 & 217.57 & 223.63 & 228.84 \\
\hline Mean & 190.91 & 215.99 & 224.04 & 233.13 & & \\
\hline \multicolumn{4}{|c|}{ Factors } & \multicolumn{2}{|c|}{$\operatorname{SEm}( \pm)$} & CD (5\%) \\
\hline \multicolumn{4}{|c|}{ Factor $(\mathrm{S})$} & \multicolumn{2}{|c|}{0.195} & 0.547 \\
\hline \multicolumn{4}{|c|}{ Factor $(\mathrm{V})$} & \multicolumn{2}{|c|}{0.175} & 0.490 \\
\hline \multicolumn{4}{|c|}{ Interaction $\mathrm{S} \times \mathrm{V}$} & \multicolumn{2}{|c|}{0.391} & 1.095 \\
\hline \multicolumn{4}{|c|}{ Factor $(\mathrm{F})$} & \multicolumn{2}{|c|}{0.151} & 0.424 \\
\hline \multicolumn{4}{|c|}{ Interaction $\mathrm{S} \times \mathrm{F}$} & \multicolumn{2}{|c|}{0.339} & 0.948 \\
\hline \multicolumn{4}{|c|}{ Interaction $\mathrm{V} \times \mathrm{F}$} & \multicolumn{2}{|c|}{0.303} & 0.848 \\
\hline \multicolumn{3}{|c|}{ Interaction $\mathrm{S} \times \mathrm{V} \times \mathrm{F}$} & & \multicolumn{2}{|c|}{0.677} & 1.896 \\
\hline
\end{tabular}

\section{Conclusion}

From the above results it can be concluded that application of vermicompost prepared from household waste either alone or in combination with chemical fertilizer significantly influenced available phosphorus and potassium content in soil. On vermicompost application there is increase in microbial activity which resulted in increased solubilisation and mineralization of $\mathrm{P}$ and $\mathrm{K}$ present in soil. Thus, during decomposition of organic matter these nutrient cations get slowly released into soil solution.

\section{References}

1. Dubey V, Patel AK, Shukla A, Shukla S, Singh S. Impact of Continuous use of Chemical Fertilizer. International
Journal of Engineering Research and Development. 2012; 3(11):13-16.

2. Edwards CA, Bohlen PJ. Biology and Ecology of Earthworms. Chapman and Hall, London. 1996; 3:426.

3. Haiba E, Ivask M, Olle L, Raamets J, Kuu A, Kutti S et al. Transformation of Nutrients and Organic Matter in Vermicomposting of Sewage Sludge and Kitchen Wastes. Journal of Agricultural Science. 2014; 6(2):14-118.

4. Jackson ML. Soil Chemical Analysis, Prentice Hall of India Pvt. Ltd., New Delhi, 1973.

5. Jatgar HS. Effects of vermicompost on physical and chemical properties of vertisol and its subsequent influence on growth, nutrient uptake and yield of maize cv. Ganga Safed-2. M.Sc. (Agri.) Thesis, Mahatma Phule Krishi Vidyapeeth, Rahuri, 1994. 
6. NEERI Report. Assessment of status of municipal solid waste management in metro cities, state capitals, class I cities and class II towns, 2005.

7. Olsen SR, Cole CV, Watanabe FS, Dean LA. Estimation of available phosphorus in soils by extraction with sodium bicarbonate. United States Department of Agriculture Circular, 1954, 939.

8. Madegowda T. Integrated nutrient management in rabi maize under irrigated conditions. M.Sc. (Agri.) Thesis, University of Agricultural Sciences, Dharwad, 1997.

9. Manivannan S, Balamurugan M, Parthasarathi K, Gunasekaran G, Ranganathan LS. Effect of vermicompost on soil fertility and crop productivitybeans (Phaseolus vulgaris). Journal of Environmental Biology. 2009; 30:275-281.

10. Murugan AV, Swarnam TP. Nitrogen Release Pattern from Organic Manures Applied to an Acid Soil. Journal of Agricultural Science. 2013; 5(6):174-184.

11. Romaniuk R, Giuffré L, Romero R. A Soil Quality Index to Evaluate the Vermicompost Amendments Effects on Soil Properties. Journal of Environmental Protection. 2011; 2:502-510.

12. Vasanthi D, Kumaraswamy K. Efficacy of vermicompost on the yield of rice and on soil fertility. Abstracts of Seminar on Organic Farming for Sustainable Agriculture. 1996; 9(11):40.

13. Washimkar SV. Effect of vermicompost on the availability of nutrients, yield and quality of foliage of mulberry grown on vertisol. M.Sc. (Agri.) Thesis, Mahatma Phule Krishi Vidyapeeth, Rahuri, 1997. 